\title{
PENERAPAN MEDIA PEMBELAJARAN FLASH CARD UNTUK MENINGKATKAN PERKEMBANGAN BAHASA ANAK
}

\author{
Pascalian Hadi Pradana $^{1}$, Febrina Gerhani ${ }^{2}$ \\ IKIP PGRI Jember ${ }^{1,2}$ \\ Pascalian10@gmail.com ${ }^{1}$
}

\begin{abstract}
ABSTRAK
Penelitian ini bertujuan untuk menerapkan media pembelajaran flash card Untuk Meningkatkan Perkembangan Bahasa Anak. Metode yang penulis gunakan untuk menentukan daerah penelitian adalah pusposive sampling. Yang berfungsi responden melalui metode observasi, dilengkapi dengan metode wawancara dan dokumentasi. Hasil penelitian, media pembelajaran flash card termasuk kartu gambar yang menarik, mudah di mainkan sehingga anak dapat merespon dan belajarnya lebih aktif. Media flash card adalah alat bantu guru untuk anak bermain dan belajar, dapat di gunakan juga di rumah dengan teman bermainnya. Hasil dari sekolah yang diajarkan oleh guru sangat baik sekali sehingga hasil perkembangan bahasa anak baik, anak dapat melaksanakan 2-3 perintah sederhana, dapat menirukan kalimat yang di sampaikan dan dapat merespon terhadap pertanyaan dengan baik. Perkembangan bahasa anak dapat menyebutkan kata-kata dengan jelas, kosa katanya baik dan bisa berbicara dengan baik setelah anaknya masuk sekolah. Simpulan, penerapan media pembelajaran flash card dapat meningkatkan perkembangan bahasa anak.
\end{abstract}

Kata Kunci: Media Flash Card, Perkembangan, Bahasa Anak

\begin{abstract}
This study aims to apply flash card learning media to improve children's language development. The method that I use to determine the research area is a purposive sampling. The function of the respondents is through the observation method, supplemented by interview methods and documentation. The results of the study, flash card learning media including attractive card images, easy to play so that children can respond and learn more actively. Flash card media is a teacher's tool for children to play and learn, can also be used at home with their playmates. The results of the school taught by the teacher are very good so that the results of children's language development are good, children can carry out 2-3 simple commands, can imitate sentences that are conveyed and can respond to questions well. Child language development can clearly state words, vocabulary is good and can speak well after the child enters school. Conclusion, the application of flash card learning media can improve children's language development.
\end{abstract}

Keywords: Flash Card Media, Development, Children's Language 


\section{PENDAHULUAN}

Untuk meningkatkan kualitas program pendidikan dalam pelaksanaannya diperlukan peran seorang pendidik (guru) dalam menjalankan proses pembelajaran supaya tujuan pendidikan tercapai. Untuk menciptakan pembelajaran yang berkualitas salah satu hal yang patut diperhatikan adalah adanya sarana sebagai alat atau media dalam pembelajaran. Sejalan dengan perkembangan zaman, media pembelajaran bukan hanya dipandang sebagai alat bantu saja oleh guru dalam proses pembelajaran namun lebih sebagai alat perantara dan pengantar dari pemberi informasi (guru) ke anak didik. Media pembelajaran tentu sangat di perlukan bagi pendidikan di Taman Kanak-kanak, hal ini karena anak usia dini pemikirannya lebih obyektif.

Adakalanya seorang guru terbuang waktunya hanya untuk menjelaskan tentang suatu hal dan anak didik tidak juga dapat memahaminya. Dari sekian anak didiknya hanya beberapa saja yang dapat memahami maksud guru. Disinilah pentingnya penggunaan media karena pada penelaahan dari pembelajaran adalah $\mathrm{suatu}$ proses interaksi dalam penyampaian informasi dari sumber informasi. Informasi disampaikan berbentuk isi dan materi bahan ajar yang ada dikurikulum.

Pendidikan adalah suatu cara dan usaha pembinaan yang dilakukan kepada peserta didik yang mana pembinaan itu di lakukan melalui pemberian stimulus dan dorongan dalam meningkatkan pertumbuhan dan perkembangan anak supaya anak menjadi matang dalam mempersiapkan dirinya kejenjang pendidikan lebih tinggi. Maka dari itu, dalam kemampuan berbahasa untuk anak para guru sebagai pendidik yang berperan sebagai motivator sekaligus fasilitator di harapkan untuk dapat meningkatkan mutu dan kualitas dalam perkembangan bahasanya.

Untuk menentukan materi pendidikan didalam pendidikan yang tergantung dua syarat yaitu alat mencapai tujuan dan struktur individualitas anak/peserta didik. Media/alat yang dipakai dalam proses untuk mencapai tujuan berdasarkan pola filsafah bangsa Indonesia. Media Flash Card ini erat kaitannya dengan saran dan prasarana baik berupa benda, situasi lingkungan, maupun kegiatan-kegiatan yang dengan sengaja ditampilkan oleh pendidik untuk mencapai tujuan sementara maupun tujuan akhir pendidikan. Menyenangkan dan menimbulkan kerinduan pada anak, pada suasana pempelajaran yang dijalankan. Bila suasana belajar mengajar itu terjadi, bukan tidak mungkin anak mencapai prestasi yang tinggi. Upaya dalam meningkatkan perkembangan kemampuan bahasa anak adalah mengenalkan tentang berbagai pengenalan huruf sebagai modal persiapan belajar membaca dijenjang pendidikan selanjutnya.

Dalam perkembangan bahasa $\mathrm{p}$ a d a anak yang efisien berdasarkan aturan dan etika bahasa. Masa usia dini sangat tepat dalam mengembangkan segala potensinya. Apabila kemampuan ini tidak dibiasakan dan dikembangkan sejak sedini mungkin sehingga masa emas pengembangan bakat dan kemampuan anak tidak berkembang secara optimal. Maka dari itu guru pendidikan anak usia 
dini yang berperan sebagai motivator sekaligus fasilitator untuk pengembangan kemampuan tersebut diharapkan untuk dapat meningkatkan mutu dan kualitas perkembangan berbahasa anak dengan menggunakan media pembelajaran yaitu media Flash Card, sehingga guru dapat menjalankan peranya dengan baik.

Media adalah perantara, penghubung, alat, dan sarana dalam menyampaikan suatu informasi atau pesan kepada penerima. Memanfaatkan media dalam pembelajaran yaitu mendukung untuk menyampaikan informasi dalam proses pembelajaran kepada siswa dalam meningkatkan kualitas dan kuantitas anak yang interaktif juga aktif sehingga bisa membantu melancarkan aktivitas proses pembelajaran didalam kelas. Adapun jenis-jenis media pembelajaran bisa digolongkan antara lain visual, audio, dan audio visual. Belajar dengan menggunakan berbagai media pembelajaran tujuan pembelajaran akan menjadi menarik dan optimal.

Proses pembelajaran di Taman Kanak-Kanak (TK) memerlukan suatu metode dan cara tersendiri dalam pencapaian kemampuan berbahasa anak. Hal ini karena kegiatan dan aktivitas anak yaitu bermain. Sedangkan anak akan belajar dari yang dilakukan segala bentuk aktivitas meraka sehari-hari. Untuk itu perlu adanya suatu media bagi sarana pembelajaran. Media pembelajaran yang tepat mampu memicu dan merangsang segenap potensi anak.Media sebagai alat bermain dan belajar sehingga dapat memberikan pengalaman pembelajaran apa, yang bagaimana, yang dapat mengkodisikan dan membelajarkan anak bagi tercapainya tumbuh kembang potensi anak secara optimal. Bermain sebagai gaya aktivitas belajar anak di sekolah maupun dirumah selayaknya bermain yang produktif dan inovatif, juga menyenangkan (tidak menumbuhkan rasa takut pada diri anak) untuk itu guru menuntut selalu menyediakan sarana berupa alat bermain/ media yang sesuai dengan kebutuhan dan minat anak. Menurut kamus besar bahasa Indonesia yang dimaksud sarana dalam arti umum yaitu semua objek yang bisa digunakan untuk alat atau media dalam menggapai harapan dan tujuan. Dalam kaitanya dengan kegiatan pembelajaran di TK, yang dimaksud dengan sarana TK yaitu segala benda yang dipakai untuk aktivitas proses belajar mengajar supaya bisa berjalan dengan efektif dan efisien sehingga pendidikan itu sendiri dapat terlaksana dan berhasil sesuai dengan tujuannya.

Proses pembelajaran di Taman Kanak-kanak (TK) memerlukan suatu metode dan cara tersendiri dalam pencapaian perkembangan bahasa pada anak. Anak-anak belajar seraya bermain dan bermain seraya belajar. Anak belajar dari bentuk aktivitas mereka masing-masing. Untuk itu perlu adanya suatu media bagi sarana pembelajaran.

Flash Card adalah kartu-kartu bergambar yang dilengkapi dengan katakata, yang diperkenalkan oleh Glenn Doman, Seorang dokter ahli bedah otak dari Philadelphia, Pennsylvania (dalam Domba, 2009). Tahap-tahap taktik menerapkan flash card, sebagai berikut 1) Kartu setelah ditata dangkat setinggi lengan dan mengarah ke anak, 2) Tarik satu persatu kartu apabila guru setelah menjelaskan, 3) 
Lalu kartu tersebut diberikan kepada siswa yang duduknya berdekatan dengan posisi guru ketika saat menjelaskan, 4) siswa lalu mengamati, dilanjutkan pada siswa yang lain sehingga semua anak bisa mendapat giliriran untuk mengamati.

Sarana perantara menggunakan Flash card termasuk kategori media pembelajaran gambar (visual). Media pembelajaran gambar mempunyai kontribusi sangat penting pada saat proses kegiatan belajar-mengajar. Kelebihan menerapkan flash card sebagai berikut a) Efektif dan efisien, b) berdaya guna, c) sensibel, dan d) me narik dan menyenangkan.

Jenis gambar pada Flash Card dikelompokkan sebagai berikut: gambar buah- buahan, gambar binatang, gambar pakaian, bentuk-bentuk angka, warna, dan sebagainya. Tetapi bukan hanya itu jenis-jenis flash card namun guru sendiri juga bisa membuat Flash Card dengan melihat sesuai kebutuhan anak atau dilingkungan tempat guru mengajar. Flash Card dapat dibeli ditoko, download di innternet, dan jika ingin beragam bentuk yang pantas atau cocok dengan kebutuhan dapat dilakukan sendiri dan bisa juga menggunakan komputer, memotong gambar majalah/koran, meskipun gambar tersebut buatan kita sendiri.

Metode dan teknik dalam pelaksanaan pengembangan berbahasa dapat menggunakan sebagai berikut: Bercerita, bercakap-cakap Tanya jawab, dan demontrasi. Dalam menggunakan metode atau teknik tersebut diatas guru dapat menerapkan beberapa metode yang cocok digunakan sesuai potensi/kemampuan yang hendak dicapai, kegiatan belajar mengajar yang disajikan dan disesuaikan pula dengan bahan pengembangan dan kebutuhan minat kemampuan anak serta lingkungannya. Dengan demikian bahwa perkembangan bahasa yaitu perubahan yang lebih baik dalam kemampuan menguasai alat berkomunikasi, baik alat komunikasi menggunakan cara tertulis, lisan, maupun bahasa isyarat. Penguasaan alat komunikasi disini diartikan sebagai usaha seseorang agar bisa memahami dan dipahami orang lain. Sejak seseorang berinteraksi dan berkomunikasi dengan orang lain penggunaan bahasa akan menjadi efektif. Perkembangan bahasa dapat dipengaruhi oleh beberapa faktor termasuk faktor lingkungan, karena di lingkungan sebagaian besar anak memperoleh kekayaan pembelajaran dalam segi meniru. Proses penerapn model ini sebelumnya guru perlu memberikan motivasi dan rangsangan pada anak misalnya dalam melakukan kegiatan diskusi atau interaksi. Adapun bentuk prasarana dalam perkembangan bahasa antara lain: sketsa gambar, buku-buku, dan lain-lain selayaknya harus ada disekolah maupun dirumah. Maka akan mengakibatkan timbunya timbal balik pada perkembangan bahasa sehingga berpengaruh pada kehidupan intelektual kecerdasan anak dan bisa menambah kekayaan potensi bahasa anak. Kehidupan intelektual yaitu ekspresi dari kemampuan yang disebut intelegensi adalah kemampuan umum untuk kemampuan berbahasa (Yeti, 2009).

Media Flash card dengan kemampuan berbahasa mempunyai keterkaitan dan ada umpan balik diantara keduanya antara lain a) menggunakan media Flash card dapat meningkatkan aktifitas siswa untuk melaksanakan kegiatan dalam 
bidang kemampuan berbahasa, b) ketrampilan komunikasi selama proses belajar mengajar dalam bidang kemampuanberbahasa dengan menggunakan media flas card dapat membantu anak mudah mengemukakan pendapatnya sehingga dalam kekmampuan berbahasa anak akan lebih baik, c) prestasi belajar dalam kemampuan berbahasa menunjukkan peningkatan setelah menggunakan media flash card anak mampu menceritakan sesuatu yang lebih baik, walaupun hanya dengan melihat urutan urutan gamnbar tersebut. Sehingga pesan yang disampaikan oleh gambar bisa dicermati oleh anak karena gambar mudah dan menarik minat anak untuk menceritakanya. (Hardiyanti, 2010).

\section{METODE PENELITIAN}

Menurut Arikunto (2013) Metode penelitian adalah cara yang digunakan oleh peneliti dalam mengumpulkan data penelitian. Dalam riset ini bertujuan untuk menerapkan media pembelajaran flash card untuk meningkatkan perkembangan bahasa anak di TK Al-Amin Kabupaten Jember. Penelitian ini menggunakan metode penelitian deskriptif kualitatif. Riset ini memakai pendekatan kualitatif yang bersifat induktif. Dalam upaya memperoleh data data yang lengkap dengan waktu yang seefisien mungkin dalam penelitian ini, maka peneliti memandang perlu menggunakan beberapa macam metode dalam pengumpulan data. Metode yang dipakai dalam riset ini untuk mengumpulkan data yaitu metode observasi, dokumentasi, dan wawancara. Tahapan yang diperoleh dalam menganalisis data diantaranya: a) reduksi data, b) penyajian data, c) kesimpulan, d) triangulasi. Triangulasi pada dasarnya merupakan multimetode yang dilaksanakan peneliti ketika mengumpulkan dan menganalisis data. Ide pokoknya yaitu bahwa fenomena yang diteliti bisa dimengerti/dipahami dengan baik sehingga dapat menghasilkan kebenaran dan kevalidan yang tinggi dilihat dari berbagai sudut pandang. Menurut Sugiyono (2011) bahwa triangulasi dimaknai sebagai teknik pengumpulan data yang bersifat menggabungkan dari berbagai teknik pengumpulan data dan sumber data yang telah ada.

\section{HASIL DAN PEMBAHASAN}

Menurut Aqib (2013) dalam memilih media pembelajaran, banyak pertimbangan yang harus dilakukan, antara lain; (1) kompetensi pembelajaran, (2) karakteristik peserta didik, (3) karakteristik media yang bersangkutan, (4) waktu yang tersedia, (5) biaya yang diperlukan, (6) ketersediaan fasilitas/peralatan, (7) konteks penggunaan, serta (8) mutu teknis media.

Menurut Hotimah (2010) Media flash card dapat menimbulkan kesenangan dan ketertarikan siswa dalam pembelajaran kosakata, karena flashcard merupakan salah satu bentuk media pembelajaran berupa kartu bergambar yang disukai siswa dan dapat disajikan dalam bentuk permainan. 
Hasil observasi Media flash card sangat menarik untuk anak-anak, karena anak dapat merepon dan belajarnya lebih aktif, dari bukti hasil belajar anak-anak dapat berkembang dengan baik sekali. Anak-anak mudah mengingat huruf, gambar, angka yang ada di media flash card. Anak dapat menyebutkan 2 kartu gambar, 3 kartu gambar binatang dengan benar. Dengan adanya media flash card anak-anak dapat belajar dengan hasil yang baik. Media flash card adalah kartu gambar yang menarik, mudah dimainkan sehingga anak dapat merespon dan belajarnya lebih aktif.

Hasil obsevasi perkembangan bahasa anak dapat menyebutkan kata-kata dengan jelas, dapat menyebut nama benda yang di perlihatkan dengan benar dan mengulang kembali kosa kata yang baru di dengar juga baik. Melaksanakan 2-3 perintah sederhana, menirukan kembali 3-4 urutan kata dan menirukan kalimat yang di sampaikan juga bisa. Mengemukakan pendapat sederhana dan merespon terhadap pertanyaan juga baik.

Hasil wawancara muridnya sangat tertarik dengan media flash card dan dapat memainkannya karena media flash card lebih mudah anak-anak untuk belajar dan mudah di ingat. Muridnya yang masih kelompok A menurut ibu guru sangat mudah sekali untuk menggunakan media flash card karena anak tertarik dengan kartu gambar yang di kenalkan oleh ibu gurunya. Muridnya bisa menirukan huruf- huruf, kata dan kalimat yang di sampaikan oleh ibu gurunya.

Hasil obsevasi bahwa media flash card adalah alat bantu guru untuk anak belajar dengan bermain, karena media flash card jenisnya bermacam-macam yaitu kartu gambar buah, binatang, huruf, angka, dll. Media flash card mudah sekali untuk di gunakan dan guru dapat membuatnya sendiri tanpa membeli dengan mahal-mahal. Media flash card sangat menarik untuk anak-anak, karena anak dapat merepon dan belajarnya lebih aktif, dari bukti hasil belajar anak-anak dapat berkembang dengan baik sekali. Anak-anak mudah mengingat huruf, gambar, angka yang ada di media flash card. Hasil wawancara dan observasi dengan guru dapat di simpulkan bahwa Media flash card adalah alat bantu guru untuk anak bermain dan belajar, medianya sangat menarik sehingga anak dapat merespon anak untuk belajarnya.

Wawancara dengan guru, muridnya bisa menirukan huruf-huruf, kata dan kalimat yang di sampaikan oleh ibu gurunya. Anak-anak merespon dari pertanyaan ibu guru Anak dapat menyebutkan kata-kata dengan jelas, dapat menyebut nama benda yang di perlihatkan dengan benar dan mengulang kembali kosa kata yang baru di dengar juga baik.

Observasi guru anak dapat melaksanakan 2-3 perintah sederhana, menirukan kembali 3-4 urutan kata dan menirukan kalimat yang di sampaikan juga bisa. Mengemukakan pendapat sederhana dan merespon terhadap pertanyaan juga baik. Hasil Perkembangan bahasa, dapat di simpulkan bahwa anak-anak merespon dari pertanyaan ibu guru, anak dapat menyebutkan kata-kata dengan jelas dan kosa katanya baik. 
Wawancara dan observasi orang tua, Perkembangan putranya setelah masuk sekolah sangat berkembang sekali. Anaknya mulai mempunyai rasa tanggung jawab dengan tugas dan kewajibannya yang didapat disekolah untuk diterapkan pula dirumah. Semangat belajarnya sangat tinggi dan kalau di rumah suka menirukan gurunya mengajar. Ternyata media yang di gunakan oleh guru sangat merespon anak-anak dan menyenangkan sekali. Hasil wawancara dengan orang tua dan observasi dapat di simpulkan bahwa Media flash card yang digunakan oleh guru di sekolah anak-anak dapat menggunakan juga di rumah dengan teman bermainnya. Hasil dari sekolah yang di ajarkan oleh gurunya sangat baik sekali. Semangat belajar anaknya sangat tinggi dan Kebiasaan anaknya jika ada tulisan di televisi, di Koran atau di ajak jalan-jalan oleh papa dan mamanya, dia membaca setiap melihat ada tulisan.

\section{SIMPULAN}

Berdasarkan hasil wawancara dan observasi anak, guru, orang tua bahwa Media flash card adalah kartu gambar yang menarik, mudah di mainkan sehingga anak dapat merespon dan belajarnya lebih aktif. Media flash card adalah alat bantu guru untuk anak bermain dan belajar, dapat di gunakan juga di rumah dengan teman bermainnya. Hasil dari sekolah yang di ajarkan oleh guru sangat baik sekali sehingga hasil perkembangan bahasa anak baik, anak dapat melaksanakan 2-3 perintah sederhana, dapat menirukan kalimat yang di sampaikan dan dapat merespon terhadap pertanyaan dengan baik. Perkembangan bahasa anak dapat menyebutkan kata-kata dengan jelas, kosa katanya baik dan bisa berbicara dengan baik setelah anaknya masuk sekolah.

\section{DAFTAR PUSTAKA}

Arikunto, S. (2013). Prosedur Penelitian. Jakarta: Rineka Cipta.

Aqib, Z. (2013). Model-model, Media, dan, Strategi Pembelajaran Kontekstual (Inovatif). Bandung: Penerbit Yrama Widya.

Domba. (2009). Kartu bergambar Flash Card. online (http://suhendra media pembelajaran.blogspot.com/2012/05/manfaat-flash-card-dalam proses.html).

Hardiyanti, E. (2010). Pengaruh Media Flash Card Terhadap Kemampuan Berbahasa Anak Kelompok B.

Hotimah, E. (2010). Penggunaan Media Flashcard Dalam Meningkatkan Kemampuan Siswa Pada Pembelajaran Kosakata Bahasa Inggris Kelas Ii Mi Ar-Rochman Samarang Garut. Jurnal Pendidikan Universitas Garut

Sugiono. (2011). Metode Penelitian Pendidikan. Bandung : Alfabeta

Yeti, M, (2009). Keterampilan Berbahasa Indonesia SD. Jakarta:Universitas Terbuka. 